\title{
Safety Assessment of Vanillic Acid: Subacute Oral Toxicity Studies in Wistar Rats
}

\section{Vanilik Asitinin Güvenlik Değerlendirmesi:Wistar Sıçanlarında Subakut Oral Toksisite Çalışmaları}

\author{
(D) Anwarbaig Chandbaig MIRZA¹, (D) Shital Sharad PANCHAL2* \\ ${ }^{1}$ Anjuman-i-Islams's Kalsekar Technical Campus, School of Pharmacy, Department of Pharmacology, Navi Mumbai, India \\ 2Nirma University Institute of Pharmacy, Department of Pharmacology, Gujarat, India
}

\begin{abstract}
Objectives: Vanillic acid (VA) is a flavoring agent, a phenolic acid, and an intermediary by-product formed during transformation of ferulic acid to vanillin. It has been investigated for diverse pharmacological actions and used in Chinese medicine for decades. However, there is no information in the literature about its mechanism of toxicity or safety with long-term use. The present study will not only supply information on its pharmacological profile but also encourage evidence-based pharmacotherapeutic use. Hence, we performed a subacute toxicity study.

Materials and Methods: According to the Organisation for Economic Co-operation and Development Test Guideline 407 (2008), 3 groups of rats were formed consisting of 12 rats ( 6 male and 6 female) in each group. For the subacute toxicity, the dose was chosen after a limit test was conducted. VA $(1000 \mathrm{mg} / \mathrm{kg} / \mathrm{day})$ was orally administered for 2 weeks to the treatment group, whereas the control group received an equivalent volume of the vehicle. To assess reversibility, VA $(1000 \mathrm{mg} / \mathrm{kg} / \mathrm{day}$, p.o.) was administered to the satellite group for 2 weeks and animals were observed for an additional 2 weeks after treatment. The adverse signs, variation in body weight, and mortality were evaluated throughout the study period. On days 15 and 29, blood was collected to evaluate essential biochemical and hematological parameters. The animals were subsequently weighed and sacrificed. The weights of internal organs were recorded; gross necroscopy and histopathological studies were performed.

Results: The hematological parameters of the satellite group increased and the serum sodium level decreased after the treatment. Satellite groups showed no other major change in biochemical parameters when compared to the control group. In addition, relative organ weights, gross necropsy examinations and histopathological structure of the internal organs showed no major alterations.

Conclusion: VA showed no adverse effect on the process of leukopoiesis, erythropoiesis or on internal organs, as verified by hematological and biochemical evaluations, gross necropsy, and histopathological studies. The decrease in serum sodium is not considered as a major toxic effect.
\end{abstract}

Key words: Subacute toxicity, vanillic acid, polyphenol, safety

öz

Amaç: Vanilik asit (VA) fenolik asit yapsında tat verici bir ajandır ve ferulik asidin vanilin dönüșümü sırasında oluşan bir ara yan üründür. Çeşitli farmakolojik etkiler için araştırılmış ve yıllardan beri Çin tıbbında kullanılmaktadır. Ancak, uzun süreli kullanımı için toksisite mekanizması veya güvenliliği ile ilgili bilgi literatürde mevcut değildir. Bu çalıșma sadece farmakolojik profile hakkında bilgi sağlamakla kalmayacak, aynı zamanda kanıta dayalı farmakoterapötik kullanımı hakkında da bilgi verecektir. Bu nedenle, subakut bir toksisite çalıșması yapılmıștır.

Gereç ve Yöntemler: Ekonomik Kalkınma ve İșbirliği Örgütü Test Kılavuzu 407 (2008)'e göre, 12 sıçan (6 erkek ve 6 diși) rastgele bir șekilde 3 gruba ayrılmıştır. Subakut toksisite için sınır testi yapıldıktan sonra doza karar verilmiştir. VA (1000 mg/kg/gün) uygulama grubuna 2 hafta boyunca oral yoldan uygulanırken kontrol grubuna eşdeğer hacimde taşıyıcı verilmiştir. Tersinirliği değerlendirmek için, uydu grubuna 2 hafta boyunca VA (1000 $\mathrm{mg} / \mathrm{kg} / \mathrm{gün}$, p.o) uygulanmış ve hayvanlar tedaviden sonra 2 hafta daha gözlenmiştir. Advers belirtiler, vücut ağırlığındaki değişiklik ve mortalite çalıșma süresi boyunca değerlenmiștir. On beșinci ve 29. günlerde, gerekli biyokimyasal ve hematolojik parametreleri değerlendirmek için kan alınmıştır. Takiben hayvanlar tartılmış ve öldürülmüştür. İç organ ağılıkları kaydedilmiş, gros nekropsi ve histopatolojik çalışmalar yapılmıştır.

Bulgular: Uydu grubunda hematolojik parametreleri artmış ve serum sodyum düzeyi uygulamadan sonra azalmıştır. Uydu gruplarında kontrol grubuna kıyasla biyokimyasal parametrelerde başka bir önemli değişiklik görülmemiştir. Ayrıca, rölatif organ ağırlığı, gros nekropsi incelemeleri ve iç organların histopatolojik yapısı önemli bir değişiklik göstermemiştir.

*Correspondence: E-mail: shital.panchal@nirmauni.ac.in, Phone: +91 9687626589 ORCID-ID: orcid.org/0000-0003-4211-8202

Received: 13.03.2019, Accepted: 30.05.2019

๑Turk J Pharm Sci, Published by Galenos Publishing House. 
Sonuç: Hematolojik ve biyokimyasal değerlendirmeler, gros nekropsi ve histopatolojik çalışmalardan da görüldüğü üzere, VA lökopoez, eritropoez ve iç vücut organları üzerinde olumsuz bir etki göstermemiștir. Serum sodyum düzeyindeki düşüş majör bir toksik etki olarak değerlendirilmemiștir Anahtar kelimeler: Subakut toksisite, vanilik asit, polifenol, güvenlik

\section{INTRODUCTION}

Vanillic acid (VA) (4-hydroxy-3-methoxybenzoic acid) is a frequently utilized flavoring agent and an oxidized form of vanillin. It is an intermediary by-product formed during transformation of ferulic acid to vanillin., ${ }^{1,2}$ It is present in large amounts in the roots of Angelica sinensis, ${ }^{3}$ fruits of Euterpe oleracea, ${ }^{4}$ wine, and vinegar ${ }^{5}$ and has been used in Chinese medicine for decades. ${ }^{6}$ It was investigated for diverse pharmacological actions in experimental animals and proved to have antidiabetic activity, ${ }^{7,8}$ an anti-inflammatory effect, ${ }^{9,10}$ a strong antioxidant effect, ${ }^{11,12}$ cardioprotectivity, ${ }^{13-15}$ thermal tolerance, ${ }^{16}$ and inhibitory effects on Neuro-2A cells. ${ }^{17}$ In addition, it ameliorates glomerulonephritis, ${ }^{18}$ has a cognitive effect in diabetic mice, ${ }^{19}$ and its presence was reported in cerebrospinal fluid. ${ }^{20}$ It was reported to inhibit carbonic anhydrase isozyme $\mathrm{II}^{21}$ and snake venom 5'-nucleotides. ${ }^{22}$ It controls transgene expression in mammalian cells and mice. ${ }^{23}$ It showed a protective effect on ulcerative colitis ${ }^{24}$ and liver toxicity ${ }^{25}$ and has a proved analeptic effect. $^{26}$ Furthermore, it acts as an antifilarial agent ${ }^{27}$ and respiratory stimulant. ${ }^{28}$

In the mid $20^{\text {th }}$ century, clinical studies were conducted on excretion of VA in urine. In one study, VA was reported as a metabolic product of 4-hydroxy-3-methoxyphenylglycol and 4-hydroxy-3-methoxymandelic acid. ${ }^{29}$ It was reported as a metabolite of protocatechuic acid, which is stable at alkaline $\mathrm{pH}$ of urine. ${ }^{30}$ In addition, excretory studies were reported in healthy volunteers, patients with circulatory and liver disorders, and smokers and nonsmokers and during stress. ${ }^{31-33}$

VA is supposed to be administered for long durations to treat chronic disorders; therefore, assessment of its safety or the risk of occurrence of toxic effects becomes crucial. Current scientific research studies revealed undesirable effects of various plant extracts and phytochemicals in rodents at higher dosages, for instance neurotoxicity (Cannabis sativa, Papaver somniferum, and Erythroxylum spp.), hepatotoxicity (Cimicifuga racemosa, etc.), genotoxicity (thymol and carvacrol), carcinogenicity (capsaicin, chili powder, safrole), cytotoxicity (Withania somnifera, safrole-2', 3'-oxide, etc.), nephrotoxicity (aristolochic acid, turmeric, etc.), teratogenicity (pyrrolizidine alkaloid monster, heliotrine), and gastrointestinal effects (red pepper, fennel, etc.). ${ }^{34}$ Brown ${ }^{35}$ discussed case studies of 12 dietary supplements and 21 herbs that give rise to a possible risk of hepatic injuries in certain individuals. These reports are alarming and compelling researchers to assess the safety of phytochemicals in long-term use. Toxicological studies on phytochemicals not only enrich the ethnopharmacology but also augment the careful utilization of phytochemicals and prevent undesirable effects, which seem to be a prime hurdle for the long-term use of modern medications. ${ }^{36}$ As per the Organisation for Economic Co-operation and Development
(OECD) TG 407 (2008), ${ }^{37}$ subacute toxicity studies are usually planned and performed after getting early details in acute toxicity studies. It improves understanding of the probable untoward effect on health likely to occur from continuous utilization of medicines over a short period and is considered a foundation for conducting subchronic and chronic toxicological studies. ${ }^{38}$ Additionally, subacute toxicology studies in experimental animals are thought to be a mandatory stage to start with for clinical trials and thereafter marketing of drug molecules. ${ }^{39}$

Acute toxicity studies on VA are reported in the literature and the LD50 value was reported as 5020 mg/kg i.p. in rats and $2691 \mathrm{mg} / \mathrm{kg}$ i.p. in mice. ${ }^{40-42}$ However, the currently available scientific literature does not contain enough data on subacute toxicity studies of VA. Hence, it was decided to perform a subacute toxicity study to determine the toxic effect (if any) of VA on physiological processes (such as erythropoiesis and leukopoiesis) and vital internal organs in rodents.

\section{MATERIALS AND METHODS}

\section{Chemicals}

VA (HSN-29189900) was procured from Sigma (St. Louis, MO, USA). Biochemical kits were purchased from Transasia BioMedicals Ltd. and Lab-Care Diagnostics (India) Pvt Ltd. All chemicals and biochemical kits were of analytical grade.

\section{Experimental animals}

Wistar albino rats of both sexes were procured from the National Institute of Bioscience, Pune. They were kept in propylene cages and room temperature of $22 \pm 1^{\circ} \mathrm{C}$ was maintained with alternate light and dark cycles. All the rats were allowed to eat high quality pelleted food and drink water ad libitum. The Institutional Animal Ethics Committee of AIKTC's, School of Pharmacy, Navi Mumbai, India approved all the experimental protocols.

\section{Limit test}

As per the OECD TG 407 (2008), ${ }^{37}$ this test was carried out by administrating one dose of VA $(2000 \mathrm{mg} / \mathrm{kg})$ to Wistar rats to make a decision about the dose of the subacute toxicity study. The animals were critically examined for any morbidity as well as mortality.

\section{Subacute toxicity}

As per the OECD TG 407 (2008), ${ }^{37} 3$ groups of rats were prepared consisting of 12 rats (6 female and 6 male) in each. The VA $(1000 \mathrm{mg} / \mathrm{kg} /$ day) was orally administered for 2 weeks to the treatment group, whereas an identical volume of vehicle was given to the control group. To check reversibility, the satellite group was orally administered VA $(1000 \mathrm{mg} /$ $\mathrm{kg} /$ day) for 2 weeks and then kept for a further 2 weeks after treatment for observation. The toxic signs, body weight 
changes, water consumption, food intake, and mortality were recorded on a weekly basis. On day 15 the rats in the control and treatment groups were exposed to isoflurane for producing an anesthetic effect and blood samples were collected in tubes coated with ethylenediaminetetraacetic acid to determine the complete blood count, which includes hemoglobin (HGB) count, white blood cell (WBC) and red blood cell (RBC) count, etc. For the other biochemical estimations nonheparinized blood samples were collected. Thereafter, all rats were sacrificed and their internal vital organs were dissected for measuring organ weight and to carry out gross anatomical studies. All isolated organs were stored in $10 \%$ buffered formaldehyde to carry out histopathological examinations.

\section{Statistical analysis}

GraphPad InStat version 3.0 (GraphPad, San Diego, CA, USA) was used to analyze the data. One-Way ANOVA was applied followed by Dunnett's multiple range test. The results were expressed as mean \pm standard deviation and $p<0.05$ was considered statistically significant.

\section{RESULTS}

\section{Limit test}

No mortality or signs of toxic effects were observed; hence as per the guideline of OECD 407 (2008), $1000 \mathrm{mg} / \mathrm{kg}$ dose was selected for the subacute toxicity study.

\section{Clinical examination, food and water consumption, and body weight}

The treatment and satellite groups did not show any signs of toxicity or mortality within the study period. Usual increases in body weights and food and water consumption were observed in the treatment and satellite groups in comparison with the rats in the control group.

\section{Hematological evaluations}

Tables 1 and 2 contain the findings of the hematological evaluations. The treatment group showed normal rises in RBC count, HGB, platelet (PLT) count, mean cell hemoglobin $(\mathrm{MCH})$, $\mathrm{MCH}$ concentration $(\mathrm{MCHC})$, packed cell volume (PCV), and mean corpuscular cell volume (MCV) in both sexes of Wistar rats but significant increases in all hematological parameters were recorded in the satellite group rats. In addition, the WBC counts of rats in the treatment and satellite groups were within the reference range and were insignificantly different compared to those of the normal control group although the neutrophil count was slightly increased in male rats in the treatment group, which was reversed after 2 weeks in the satellite group (Table 2). The eosinophil, monocyte, and lymphocyte counts in the treated and satellite groups showed no remarkable change in comparison with the rats in the normal control group.

\section{Blood biochemistry}

The findings of the clinical biochemistry analysis are shown in Table 3. It involves estimation of lactate dehydrogenase $(\mathrm{LDH})$, total protein (TP), creatinine (CR), total bilirubin (TB), direct bilirubin (DB), blood glucose (BG), serum glutamic- oxaloacetic transaminase (SGOT), serum glutamine-pyruvic transaminase (SGPT), albumin (ALB), electrolytes [potassium $(\mathrm{K})$, calcium $(\mathrm{Ca})$, chloride $(\mathrm{Cl})$, and phosphate $(\mathrm{P})]$, blood urea nitrogen (BUN), alkaline phosphatase (ALP), and lipid profile [triglycerides (TGs), total cholesterol (TC), and high density lipoprotein (HDL)]. Application of VA to the treatment group rats caused no shift in biochemical parameters in comparison with the normal control rats except for statistically significant decreased sodium levels in the male treatment group, which did not recover in the satellite group to normal levels.

Relative organ weight, gross necropsy, and histopathological findings

Table 4 shows the effect of VA on relative internal organ weight. No significant variation was observed in relative organ weights of the treatment and satellite groups in comparison with the normal control group, although the liver weight of treated rats (male) was high in comparison to that of normal control rats, but it was reversed in the respective satellite group. Gross anatomical examination of vital organs and/or systems of rats

Table 1. Effect of vanillic acid on hematological evaluations at the end of the study

\begin{tabular}{|c|c|c|c|}
\hline Gender \& parameters & Groups & & \\
\hline Male & Control & $V^{t}$ & $\mathrm{VA}^{\mathrm{s}}$ \\
\hline $\mathrm{Hb}(\mathrm{g} \%)$ & $13.00 \pm 0.44$ & $12.42 \pm 0.63$ & $14.53 \pm 0.58^{*}$ \\
\hline $\mathrm{RBC}\left(\times 10^{6} / \mathrm{mm}^{3}\right)$ & $7.34 \pm 0.23$ & $6.82 \pm 0.12$ & $8.62 \pm 0.43^{\star}$ \\
\hline WBC $\left(\times 10^{3} / \mathrm{mm}^{3}\right)$ & $11.88 \pm 3.74$ & $11.30 \pm 1.61$ & $11.30 \pm 3.89$ \\
\hline PLT (x105/mm 3$)^{3}$ & $9.48 \pm 1.20$ & $7.37 \pm 1.15$ & $9.50 \pm 0.96$ \\
\hline PCV (\%) & $33.86 \pm 1.29$ & $29.40 \pm 5.06$ & $46.71 \pm 2.31^{*}$ \\
\hline$M C V(f L)$ & $46.06 \pm 0.56$ & $50.50 \pm 1.17^{*}$ & $54.20 \pm 0.91$ * \\
\hline $\mathrm{MCH}(p g)$ & $17.61 \pm 0.23$ & $18.93 \pm 0.79$ & $16.80 \pm 0.38^{*}$ \\
\hline $\mathrm{MCHC}(\mathrm{g} / \mathrm{dL})$ & $38.33 \pm 0.42$ & $37.93 \pm 1.97$ & $31.08 \pm 0.65^{*}$ \\
\hline \multicolumn{4}{|l|}{ Female } \\
\hline HGB (g \%) & $12.35 \pm 0.80$ & $12.46 \pm 0.58$ & $14.25 \pm 0.52 *$ \\
\hline $\mathrm{RBC}\left(\times 10^{6} / \mathrm{mm}^{3}\right)$ & $6.89 \pm 0.40$ & $6.79 \pm 0.27$ & $7.90 \pm 0.38^{*}$ \\
\hline WBC $\left(x 10^{3} / \mathrm{mm}^{3}\right)$ & $10.13 \pm 2.91$ & $10.45 \pm 2.77$ & $11.78 \pm 3.60$ \\
\hline PLT $\left(x 10^{5} / \mathrm{mm}^{3}\right)$ & $8.87 \pm 1.79$ & $7.94 \pm 0.59$ & $9.38 \pm 1.81$ \\
\hline PCV (\%) & $32.73 \pm 1.90$ & $33.61 \pm 1.61$ & $45.31 \pm 2.03^{*}$ \\
\hline$M C V(f L)$ & $47.58 \pm 0.75$ & $49.58 \pm 1.23^{*}$ & $57.38 \pm 1.17^{\star}$ \\
\hline $\mathrm{MCH}(p g)$ & $17.88 \pm 0.33$ & $18.30 \pm 0.37$ & $18.01 \pm 0.41$ \\
\hline $\mathrm{MCHC}(\mathrm{g} / \mathrm{dL})$ & $37.66 \pm 0.75$ & $37.05 \pm 0.95$ & $31.4 \pm 0.42^{*}$ \\
\hline
\end{tabular}

Values are presented as mean $\pm \mathrm{SD}$, * significantly different from control, $\mathrm{p}<0.05$ $V^{t}$ is a group of rats that received treatment of VA $(1000 \mathrm{mg} / \mathrm{kg}$ p.o.) for 2 weeks and were then sacrificed

$V^{\mathrm{s}}$ is a group of rats that received treatment of VA (1000 mg/kg p.o.) for 2 weeks, kept under observation for an additional 2 weeks without treatment, and then sacrificed

VA: Vanillic acid, HGB: Hemoglobin, RBC: Red blood cell, WBC: White blood cell, PLT: Platelet, PCV: Packed cell volume, MCV: Mean corpuscular cell volume, MCH: Mean cell hemoglobin, MCHC: Mean cell haemoglobin concentration, SD: Standard deviation 
in the treatment and satellite groups did not show any major irregularities in comparison to normal control group rats.

Microscopically, normal histomorphological structures with intact length of nerve fibers and normal cellular details were observed in tissue sections of the sciatic nerve. Sections of the brain showed intact supporting matrix and normal histomorphological structures of neurons. Heart sections of the treatment group revealed no changes in the structures of cardiac muscle fiber, and cardiac fibers were found to be organized in a compact and dense manner, having normal nuclei and cell striation with intact length. Renal tissue slices revealed no major structural alteration in renal tubules and glomeruli. Liver tissue showed normal structures of hepatocytes, central veins, and portal triads in intact hepatic parenchyma. Hepatocytes had normal intact nuclei and cellular borders and were arranged as cords. Histopathological sections did not show any inflammatory or metabolic changes. Representative sections of the histological studies are shown in Figure 1.

\section{DISCUSSION}

VA is a flavoring agent and found to have diverse pharmacological actions. $^{7-28}$ The safety of VA in future use may be a major concern specifically to make a decision about the optimum dose and to avoid untoward effects, but such information is lacking in the present scientific literature. A subacute toxicity study is preliminary to a chronic study. ${ }^{37,43}$ In addition, the results of the present study will not only enrich the pharmacological profile of VA but also encourage evidencebased pharmacotherapeutic use. In the light of these facts, we conducted a subacute toxicity study. Initially, a limit test was carried out, which helped us to make a decision about the dose of VA for the subacute toxicity study by oral administration of one dose of $2000 \mathrm{mg} / \mathrm{kg}$. Rats showed no signs of toxicity or mortality. Hence, it can be concluded that VA (1000 mg/kg b.w.) could be safe for use in a subacute toxicity study.

The study was designed by referring to OECD TG 407 (2008). ${ }^{37}$ All essential examinations were included in the study, such as daily observation for toxic signs, mortality, measurement of weights, water intake, food consumption, all hematological and biochemical estimations within the blood, gross necropsy, and histopathological studies of the vital internal organs. However, we would like to declare that not all examination mentioned in OECD TG 407 were included in the study (such as urine analysis, estimation of T3, T4, TSH hormone, and cholinesterase).

Clinical observation for toxic signs, food and water consumption, and body weight measurements helped us to monitor progression from covert toxicity to overt signs. If the rat is not in a state of well-being it will not consume enough food or drink the necessary quantity of water. Therefore, clinical observation, food and water intake, and body weights are the indicators of general health and relative organ weight indicates organ toxicity, which may be revealed by hypertrophy and/or hyperplasia. Hence, these evaluations are pivotal in subacute toxicity studies. ${ }^{43-45}$ Rats in the treatment and satellite groups received VA (1000 mg/kg/day) orally for 2 weeks and they were monitored daily during the dosing period for any mortality or signs of toxicity like physiological activities (e.g., pilomotor reflex, abnormal breathing pattern, pupil size, lacrimation), abnormalities of the skin, mucous membranes, fur, and eyes, and occurrence of secretions. Postural changes and reactions to gait and handling were monitored along with the presence of

Table 2. Effect of vanillic acid on differential leukocyte count at the end of the study

\begin{tabular}{|c|c|c|c|}
\hline \multirow{2}{*}{ Gender \& parameters } & \multicolumn{3}{|l|}{ Group } \\
\hline & Control & $\mathrm{VA}^{\mathrm{t}}$ & $\mathrm{VA}^{\mathrm{s}}$ \\
\hline \multicolumn{4}{|l|}{ Male } \\
\hline Neutrophil \% & $44.66 \pm 8.80$ & $45.83 \pm 10.34$ & $59.12 \pm 7.88^{*}$ \\
\hline Eosinophil \% & $2.83 \pm 2.85$ & $6.00 \pm 7.45$ & $1.00 \pm 0.89$ \\
\hline Monocyte \% & $1.50 \pm 1.76$ & $0.66 \pm 0.51$ & $0.83 \pm 0.75$ \\
\hline \multicolumn{4}{|l|}{ Female } \\
\hline WBC $\left(x 10^{3} / \mathrm{mm}^{3}\right)$ & $10.13 \pm 2.91$ & $10.45 \pm 2.77$ & $11.78 \pm 1.47$ \\
\hline Neutrophil \% & $44.00 \pm 17.29$ & $47.33 \pm 11.72$ & $60.00 \pm 5.93$ \\
\hline Monocyte \% & $0.66 \pm 0.51$ & $0.66 \pm 0.51$ & $0.66 \pm 0.51$ \\
\hline
\end{tabular}

Values are presented as mean $\pm \mathrm{SD}$, * significantly different from control, $\mathrm{p}<0.05$

$V A^{t}$ is a group of rats that received treatment of VA $(1000 \mathrm{mg} / \mathrm{kg}$ p.o.) for 2 weeks and were then sacrificed

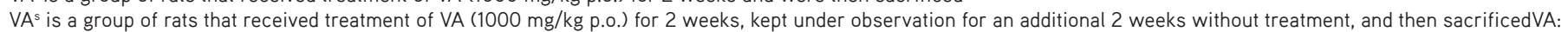
Vanillic acid,

VA: Vanillic acid, SD: Standard deviation, WBC: White blood cell 


\begin{tabular}{|c|c|c|c|}
\hline \multirow{2}{*}{$\begin{array}{l}\text { Gender \& } \\
\text { parameters }\end{array}$} & \multicolumn{3}{|l|}{ Group } \\
\hline & Control & $V^{t}$ & $\mathrm{VA}^{\mathrm{s}}$ \\
\hline \multicolumn{4}{|l|}{ Male } \\
\hline $\mathrm{BG}(\mathrm{mg} / \mathrm{dL})$ & $89.26+10.42$ & $97.22+9.83$ & $91.58 \pm 7.18$ \\
\hline BUN (mg/dL) & $20.24+1.94$ & $21.44+2.12$ & $20.82 \pm 1.72$ \\
\hline $\mathrm{CR}(\mathrm{mg} / \mathrm{dL})$ & $0.51 \pm 0.04$ & $0.52 \pm 0.02$ & $0.50 \pm 0.09$ \\
\hline $\mathrm{TP}(\mathrm{g} / \mathrm{dL})$ & $6.48 \pm 0.76$ & $7.21 \pm 0.42$ & $7.18 \pm 0.41$ \\
\hline ALB (g/dL) & $4.97 \pm 0.23$ & $5.17 \pm 0.22$ & $5.02 \pm 0.21$ \\
\hline TB (mg/dL) & $0.21 \pm 0.03$ & $0.23 \pm 0.03$ & $0.22 \pm 0.04$ \\
\hline $\mathrm{DB}(\mathrm{mg} / \mathrm{dL})$ & $0.062 \pm 0.01$ & $0.093 \pm 0.07$ & $0.086+0.04$ \\
\hline SGOT (U/L) & $84.32 \pm 7.32$ & $83.62 \pm 3.63$ & $81.17 \pm 7.23$ \\
\hline SGPT (U/L) & $32.81 \pm 3.73$ & $34.33+3.05$ & $32.58+2.11$ \\
\hline ALP (U/L) & $262.48+6.69$ & $256.58+31.28$ & $250.24+33.79$ \\
\hline $\mathrm{Ca}(\mathrm{mg} / \mathrm{dL})$ & $11.21+0.78$ & $11.19+0.63$ & $10.74+1.09$ \\
\hline$K(m E q / L)$ & $7.54+1.89$ & $7.41+0.46$ & $8.08+1.18$ \\
\hline $\mathrm{Cl}(\mathrm{mEq} / \mathrm{L})$ & $103.76+5.69$ & $110.53+14.61$ & $106.79 \pm 7.19$ \\
\hline $\mathrm{Na}(\mathrm{mEq} / \mathrm{L})$ & $86.03+4.90$ & $63.66+7.46^{*}$ & $58.33+10.24^{*}$ \\
\hline$P(\mathrm{mg} / \mathrm{dL})$ & $5.93+1.87$ & $5.38+0.69$ & $5.19+0.62$ \\
\hline LDH (U/L) & $361.44+82.50$ & $408.53+78.92$ & $384.54 \pm 34.89$ \\
\hline HDL (mg/dL) & $20+3.53$ & $20.41+3.68$ & $21.25+4.67$ \\
\hline $\mathrm{CHL}(\mathrm{mg} / \mathrm{dL})$ & $81.44+7.92$ & $79.23+6.26$ & $82.27 \pm 7.61$ \\
\hline TG (mg/dL) & $110.66+6.22$ & $113.39+7.29$ & $112.88 \pm 5.45$ \\
\hline \multirow{2}{*}{$\begin{array}{l}\text { Gender \& } \\
\text { Parameters }\end{array}$} & \multicolumn{3}{|l|}{ Group } \\
\hline & Control & $\mathrm{VA}^{t}$ & $V^{s}$ \\
\hline \multicolumn{4}{|l|}{ Female } \\
\hline $\mathrm{BG}(\mathrm{mg} / \mathrm{dL})$ & $98.23+13.75$ & $96.35 \pm 8.04$ & $97.52+11.86$ \\
\hline $\mathrm{BUN}(\mathrm{mg} / \mathrm{dL})$ & $22.07+11.67$ & $20.16+4.61$ & $21.96 \pm 2.28$ \\
\hline $\mathrm{CR}(\mathrm{mg} / \mathrm{dL})$ & $0.49+0.10$ & $0.50 \pm 0.07$ & $0.52 \pm 0.05$ \\
\hline $\mathrm{TP}$ (g/dL) & $7.37 \pm 0.48$ & $7.24+0.19$ & $7.19+0.35$ \\
\hline ALB (g/dL) & $4.99+0.39$ & $5.05+0.36$ & $5.12+0.26$ \\
\hline $\mathrm{TB}(\mathrm{mg} / \mathrm{dL})$ & $0.24 \pm 0.04$ & $0.22 \pm 0.04$ & $0.25 \pm 0.04$ \\
\hline $\mathrm{DB}(\mathrm{mg} / \mathrm{dL})$ & $0.081+0.05$ & $0.11 \pm 0.05$ & $0.09 \pm 0.04$ \\
\hline SGOT (U/L) & $73.08+9.29$ & $77.67 \pm 4.96$ & $80.121 \pm 7.20$ \\
\hline SGPT (U/L) & $28.80 \pm 3.94$ & $30.26+3.77$ & $32.58+3.05$ \\
\hline ALP (U/L) & $152.77 \pm 12.80$ & $156.4+10.98$ & $150.50+18.81$ \\
\hline $\mathrm{Ca}(\mathrm{mg} / \mathrm{dL})$ & $11.38+1.02$ & $11.15+1.06$ & $10.99+1.01$ \\
\hline $\mathrm{K}(\mathrm{mEq} / \mathrm{L})$ & $8.75+0.85$ & $7.95+0.78$ & $7.62+1.64$ \\
\hline $\mathrm{Cl}(\mathrm{mEq} / \mathrm{L})$ & $106.77 \pm 7.27$ & $107.5+6.62$ & $110.60 \pm 9.49$ \\
\hline $\mathrm{Na}(\mathrm{mEq} / \mathrm{L})$ & $82.33+15.46$ & $71.79+9.86$ & $70.17 \pm 5.85$ \\
\hline
\end{tabular}

\begin{tabular}{llll}
\hline $\mathrm{P}(\mathrm{mg} / \mathrm{dL})$ & $6.11 \pm 0.73$ & $6.28 \pm 0.95$ & $6.27 \pm 1.19$ \\
\hline $\mathrm{LDH}(\mathrm{U} / \mathrm{L})$ & $473.90 \pm 117.43$ & $424.96 \pm 11.68$ & $397.71 \pm 29.38$ \\
\hline $\mathrm{HDL}(\mathrm{mg} / \mathrm{dL})$ & $21.66 \pm 4.37$ & $20 \pm 3.53$ & $21.25 \pm 4.67$ \\
\hline $\mathrm{CHL}(\mathrm{mg} / \mathrm{dL})$ & $87.96 \pm 4.14$ & $85.83 \pm 6.58$ & $86.73 \pm 5.66$ \\
\hline $\mathrm{TG}(\mathrm{mg} / \mathrm{dL})$ & $108.37 \pm 8.08$ & $106.12+5.54$ & $105.27+4.53$ \\
\hline
\end{tabular}

Values are presented as mean \pm SD. *significantly different from control, p<0.05 $V A^{t}$ is a group of rats which received treatment of VA $(1000 \mathrm{mg} / \mathrm{kg} \mathrm{p.0})$ for 2 weeks and then sacrificed, VAs is a group of rats which received treatment of VA (1000 $\mathrm{mg} / \mathrm{kg} \mathrm{p.o)}$ for 2 weeks; kept under observation for an additional 2 weeks without treatment and then sacrificed

BG: Blood glucose, BUN: Blood urea nitrogen, CR: Creatinine,TP: Total protein, ALB: Albumin, TB: Total bilirubin, DB: Direct bilirubin, SGOT: Serum glutamicoxaloacetic transaminase, SGPT: Serum glutamine-pyruvic transaminase, ALP: Alkaline phosphatase, Ca: Calcium, K: Potassium, Cl: Chloride, Na: Sodium, P: Phosphate, LDH: Lactate dehydrogenase, HDL: High density lipoprotein, TG: Triglycerides

activities (e.g., immoderate grooming, continuous circling) or strange actions and clonic/tonic movements. ${ }^{37}$ The treatment and satellite groups did not show any signs of toxicity or mortality within the course of the study period in comparison with the normal control group. In addition, the treatment and satellite groups showed a normal increment in body weight, water consumption, and food intake. Table 4 shows the effect of VA on relative internal organ weight. The liver weight of treated rats (male) was high in comparison to the normal control rats, but it was reversed in the respective satellite group. Increase in liver weight was considered an adaptive and nonadverse reaction. ${ }^{46}$ Other internal organs in the treatment group did not manifest any remarkable impact on internal organ weight.

Biochemical estimations in the blood and hematological evaluations are important indicators in finding out the mechanism of toxic effects ${ }^{47-49}$ and the parameters were selected not only to detect target organ toxicity but also to detect pretoxic changes that might predict impending toxicity. ${ }^{38,43}$ The results are shown in Tables 1-3. The RBC, PCV, $\mathrm{HGB}, \mathrm{MCH}, \mathrm{MCV}, \mathrm{MCHC}$, and PLT counts of male and female rats in the treatment group did not reveal any remarkable increase when compared with the normal control group. Significant increases in all the hematological parameters were observed in rats in the satellite group, which were within the reference range, and this cannot be regarded as an undesirable effect of VA. ${ }^{50}$ This can be justified by considering the contrasting situation of the decline in the RBC and HGB counts and other hematological evaluations, which confirmed anemic condition and untoward impact on functioning of erythropoietic stem cells. In addition, the WBC counts of rats in the treatment and satellite groups were within the reference range and had no remarkable difference when compared with the normal control group, although the neutrophil count was slightly increased in the satellite group in both sexes. This, however, cannot be considered a consequence of infection and inflammation. The eosinophil, monocyte, and lymphocyte counts in the treatment and satellite groups showed no remarkable changes when compared with the normal control group. Therefore, it might be concluded that VA is nontoxic and did not alter the function or efficacy of myeloid tissue. 
Table 3 shows the effect of VA on biochemical evaluations. The plasma levels of TP, CR, TB, BG, ALB, electrolytes ( $\mathrm{K}, \mathrm{Ca}, \mathrm{Cl}, \mathrm{P})$, BUN, ALP, and lipid profile (TG, TC, and HDL) were unaltered. However, some of the biochemical parameters showed nonsignificant alterations in male and female rats, which included DB, SGOT, SGPT, and Na levels. DB, SGOT, SGPT, and ALB levels are important indicators of liver function..$^{51}$ In male treated and satellite group rats, an insignificant high level of DB was observed in comparison with the respective control group; even so no major alteration was reported in other liver function tests (SGOT and SGPT). In female rats, DB level was nonsignificantly increased among the treated rats, but reversed within the satellite group with slightly increased SGPT and SGOT levels in the treatment and satellite groups. All the alterations were nonsignificant and not in coordination with the macroscopic and histopathological findings in the liver (Figure 1), conducted to correlate the biochemical findings of the liver. ${ }^{39,43}$ Furthermore, albumin levels were not significantly altered in female and male rats. On the basis of these findings, it can be concluded that VA does not have any subacute toxic effect on the liver.

The effect of VA on renal function was assessed by estimation of BUN, CR, TP, and LDH levels. ${ }^{52,53}$ No statistically remarkable

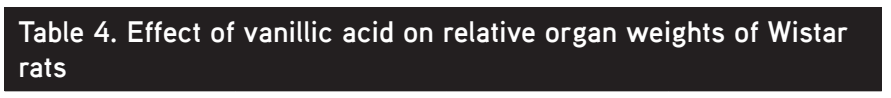

\begin{tabular}{|c|c|c|c|}
\hline \multicolumn{4}{|c|}{ Organ weight ( $\mathrm{g} \%$ body weight) } \\
\hline \multicolumn{4}{|c|}{ Treatment group } \\
\hline Organs & Control & $\mathrm{VA}^{\mathrm{t}}$ & $\mathrm{VA}^{\mathrm{s}}$ \\
\hline \multicolumn{4}{|l|}{ Male } \\
\hline Lung & $0.47 \pm 0.01$ & $0.46 \pm 0.01$ & $0.48 \pm 0.01$ \\
\hline Heart & $0.37 \pm 0.01$ & $0.39 \pm 0.05$ & $0.38 \pm 0.01$ \\
\hline Liver & $3.71 \pm 0.04$ & $3.76 \pm 0.05^{\star}$ & $3.69 \pm 0.01$ \\
\hline Spleen & $0.37 \pm 0.01$ & $0.37 \pm 0.01$ & $0.38 \pm 0.01$ \\
\hline Kidney & $0.47 \pm 0.001$ & $0.45 \pm 0.02$ & $0.48 \pm 0.001$ \\
\hline Testis & $0.63 \pm 0.02$ & $0.61 \pm 0.03$ & $0.60 \pm 0.03$ \\
\hline Adrenal & $0.017 \pm 0.001$ & $0.016 \pm 0.001$ & $0.016 \pm 0.001$ \\
\hline \multicolumn{4}{|l|}{ Female } \\
\hline Lung & $0.49 \pm 0.001$ & $0.48 \pm 0.004$ & $0.49 \pm 0.01$ \\
\hline Heart & $0.31 \pm 0.02$ & $0.26 \pm 0.05$ & $0.28 \pm 0.01$ \\
\hline Liver & $2.92 \pm 0.11$ & $2.78 \pm 0.23$ & $2.82 \pm 0.17$ \\
\hline Spleen & $0.25 \pm 0.01$ & $0.23 \pm 0.02$ & $0.22 \pm 0.02$ \\
\hline Kidney & $0.46 \pm 0.07$ & $0.39 \pm 0.03$ & $0.39 \pm 0.06$ \\
\hline Ovary & $0.11 \pm 0.01$ & $0.09 \pm 0.005$ & $0.091 \pm 0.01$ \\
\hline Adrenal & $0.016 \pm 0.001$ & $0.014 \pm 0.001$ & $0.016 \pm 0.001$ \\
\hline \multicolumn{4}{|c|}{$\begin{array}{l}\text { Values are presented as mean } \pm \text { SD. }{ }^{*} \text { significantly different from control, p<0.05 } \\
\text { VAt is a group of rats that received treatment of VA ( } 1000 \mathrm{mg} / \mathrm{kg} \text { p.o.) for } 2 \text { weeks } \\
\text { and were then sacrificed, VAs is a group of rats that received treatment of VA (1000 } \\
\mathrm{mg} / \mathrm{kg} \text { p.o.) for } 2 \text { weeks, kept under observation for an additional } 2 \text { weeks withou } \\
\text { treatment, and then sacrificed } \\
\text { SD: Standard deviation, VA: Vanillic acid }\end{array}$} \\
\hline
\end{tabular}

change was recorded in the renal functional parameters of male and female rats in the treatment and satellite groups. The above evaluations showed that oral administration of VA may not alter the renal function, which is in concurrence with normal renal macroscopic and histopathological findings (Figure 1) of female and male rats in the satellite and treatment groups.

Electrolytes ( $\mathrm{K}, \mathrm{Na}, \mathrm{P}$, and $\mathrm{Ca}$ ) in serum were evaluated during subacute toxicity studies. ${ }^{54,55}$ In our study, $\mathrm{P}, \mathrm{K}$, and $\mathrm{Ca}$ evaluation did not show any statistically remarkable change within the treatment and satellite groups in comparison with the normal control group. Although a significant decline in $\mathrm{Na}$ level was observed in male rats in the treatment and satellite groups, a statistically insignificant high level was reported in female rats in the treatment group in comparison with the normal control group. Based on the available knowledge of electrolyte balance, we can propose the probable mechanism behind reduced serum $\mathrm{Na}$ level. Firstly, it could be increased urinary loss and high cellular uptake. ${ }^{56}$ Secondly, the process may be mediated by antidiuretic hormone and atrial natriuretic peptide. ${ }^{56}$ However, this might not be viewed as a serious unsafe effect because a $\mathrm{Na}$ level below $20 \mathrm{mEq} / \mathrm{L}$ can only indicate $\mathrm{Na}$ leakage from damaged renal tubules or hypovolemia ${ }^{57}$ or this effect can be recognized as a side effect as in the case of all classes of antidepressant drugs. ${ }^{58}$ Repeated administration of

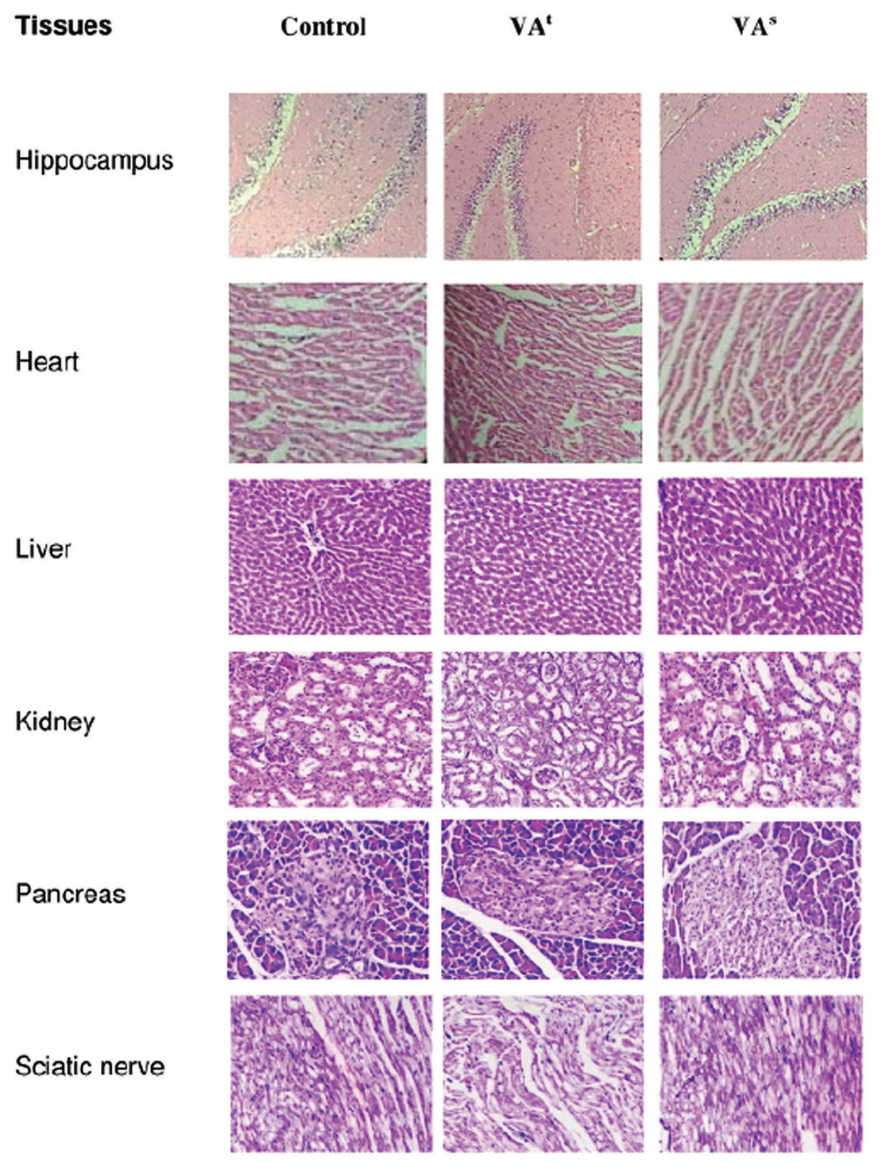

Figure 1. Effect of vanillic acid on the histomorphology of the vital organs of the rat

VA: Vanillic acid 
VA does not affect the lipid profile of male and female rats. Thus, it is apparent that oral dosing of VA does not influence the electrolyte balance or the process of lipid metabolism.

Gross necropsy and histopathological studies represent the cornerstone within the process of safety evaluation before trials in human patients, essential to find out any relationship and relevance of treatment-related findings. ${ }^{39,43}$ In our study, the toxic effect on internal vital organs (i.e. brain, heart, liver, kidney, and sciatic nerve) was evaluated by gross necropsy and histopathological studies (Figure 1), which revealed no abnormality in any vital major organs. Thus, the result indicates that the VA is reasonably safe at the selected subacute dose.

\section{CONCLUSION}

VA is a polyphenol with diverse pharmacological actions, but no information on subacute toxicity studies is available in the current literature. To enrich its pharmacological profile and encourage its evidence-based pharmacotherapeutic use, a subacute toxicity study was conducted using experimental rats. To summarize, no mortality or clinical toxic signs were recorded during the study period; normal rises in body and internal organ weight were observed. The processes of leukopoiesis, erythropoiesis, and physiology of internal organs were not changed and no structural deformities were detected in the gross necropsy or histopathological studies of vital internal organs. The serum Na level was decreased in male Wistar rats with no major changes in levels of the other electrolytes, and this cannot be categorized as a major toxic effect. Hence, it can be concluded that the VA is safe in experimental rats during subacute toxicity studies. Further subchronic and chronic toxicological research is needed to investigate the safety characteristics of VA.

\section{ACKNOWLEDGEMENTS}

The authors really appreciate the assistance provided by NIRMA University and Al's Kalsekar Technical Campus to finish the study. The authors also appreciate the financial support given by Mumbai University to finish the research work.

Conflicts of interest: No conflict of interest was declared by the authors. The authors alone are responsible for the content and writing of the paper.

\section{REFERENCES}

1. Lesage ML, Delattre M, Haon M, Thibault JF, Ceccaldi BC, Brunerie $\mathrm{P}$, Asther M. A two-step bioconversion process for vanillin production from ferulic acid combining Aspergillus niger and Pycnoporus cinnabarinus. J Biotechnol. 1996;50:107-113.

2. Civolani C, Barghini P, Roncetti AR, Ruzzi M, Schiesser A. Bioconversion of ferulic acid into vanillic acid by means of a vanillate-negative mutant of Pseudomonas fluorescens strain BF13. Appl Environ Microbiol. 2000;66:2311-2317.

3. Duke JA. Database of Phytochemical Constituents of GRAS Herbs and Other Economic Plants. Boca Raton; CRC Press; 1992.

4. Pacheco-Palencia LA, Mertens-Talcott S, Talcott ST. Chemical composition, antioxidant properties, and thermal stability of a phytochemical enriched oil from Acai (Euterpe oleracea Mart.). J Agric Food Chem. 2008;56:4631-4636.

5. Galvez MC, Barroso CG, Pérez-Bustamante JA. Analysis of polyphenolic compounds of different vinegar samples. Z Lebensm Unters Forch. 1994;199:29-31.

6. Prabhakar PK, Doble M. Effect of Natural Products on Commercial Oral Antidiabetic Drugs in Enhancing 2-Deoxyglucose Uptake by 3T3-L1 Adipocytes. Ther Adv Endocrinol Metab. 2011;2:103-114.

7. Chang WC, WU JSB, Chen CW, Kuo PL, Chien HM, Wang YT, Shen SC. Protective Effect of Vanillic Acid against Hyperinsulinemia, Hyperglycemia and Hyperlipidemia via Alleviating Hepatic Insulin Resistance and Inflammation in High-Fat Diet (HFD)-Fed Rats. Nutrients. 2015;7:9946-9959.

8. Klinger $W$, Kersten $L$. The effect of vanillic acid diethylamide on the blood sugar in rabbits and ascorbic acid in the liver and adrenal glands in rats. Acta Biol Med Ger. 1963;10:689-690.

9. Calizto-Compos C, Carvalho TT, Hohmann MSN, Pinho-Ribeiro FA, Fattori V, MAnchope MF, Zarpelon AC, Baracat MM, Georgetti SR, Casagrande R, Verri Jr WA. Vanillic Acid Inhibits Inflammatory Pain by Inhibiting Neutrophil Recruitment, Oxidative Stress, Cytokine Production, and NFKB Activation in Mice. J Nat Prod. 2015;78:17991808.

10. Kim MC, Kim SJ, Kim DS, Jeon YD, Park SJ, Lee HS, Um JY, Hong $\mathrm{SH}$. Vanillic acid inhibits inflammatory mediators by suppressing $\mathrm{NF}-\kappa \mathrm{B}$ in lipopolysaccharide-stimulated mouse peritoneal macrophages. Immunopharmacol Immunotoxicol. 2011;33:525-532.

11. Tai A, Sawano T, Ito H. Antioxidative properties of vanillic acid esters in multiple antioxidant assays. Biosci Biotechnol Biochem. 2012;76:314-318.

12. Chou TH, Ding HY, Hung WJ, Liang $\mathrm{CH}$. Antioxidative characteristics and inhibition of alpha-melanocyte-stimulating hormone-stimulated melanogenesis of vanillin and vanillic acid from Origanum vulgare. Exp Dermatol. 2010;19:742-750.

13. Dianat M, Radmanesh E, Badavi M, Goudarzi G, Mard SA. The effects of PM10 on electrocardiogram parameters, blood pressure and oxidative stress in healthy rats: the protective effects of vanillic acid. Environ Sci Pollut Res Int. 2016;23:19551-19560.

14. Dianat M, Hamzavi GR, Badavi M, Samarbaf-zadeh A. Effect of vanillic acid on ischemia-reperfusion of isolated rat heart: Hemodynamic parameters and infarct size assays. Indian J Exp Biol. 2015;53:641-646.

15. Stanely Mainzen Prince P, Dhanasekar K, Rajakumar S. Vanillic acid prevents altered ion pumps, ions, inhibits Fas-receptor and caspase mediated apoptosis-signaling pathway and cardiomyocyte death in myocardial infarcted rats. Chem Biol Interact. 2015;232:68-76.

16. Yemiş GP, Pagotto F, Bach S, Delaquis P. Thermal tolerance and survival of Cronobacter sakazakii in powdered infant formula supplemented with vanillin, ethyl vanillin, and vanillic acid. J Food Sci. 2012;77:M523-M527.

17. Huang SM, Hsu CL, Chuang HC, Shih PH, Wu CH, Yen GC. Inhibitory effect of vanillic acid on methylglyoxal-mediated glycation in apoptotic Neuro-2A cells. Neurotoxicology. 2008;29:1016-1022.

18. Motiram Kakalij R, Tejaswini G, Patil MA, Dinesh Kumar B, Diwan PV. Vanillic Acid Ameliorates Cationic Bovine Serum Albumin Induced Immune Complex Glomerulonephritis in BALB/c Mice. Drug Dev Res. 2016;77:171-179.

19. Singh JC, Kakalij RM, Kshirsagar RP, Kumar BH, Komakula SS, Diwan PV. Cognitive effects of vanillic acid against streptozotocin-induced neurodegeneration in mice. Pharm Biol. 2015;53:630-636.

20. Alzweiri M, Al-Hiari Y. Evaluation of vanillic acid as inhibitor of carbonic anhydrase isozyme III by using a modified Hummel-Dreyer method: approach for drug discovery. Biomed Chromatogr. 2013;27:1157-1161. 
21. Alzweiri M, Al-Hiari Y. Evaluation of vanillic acid as inhibitor of carbonic anhydrase isozyme III by using a modified Hummel-Dreyer method: approach for drug discovery. Biomed Chromatogr. 2013;27:1157-1161.

22. Dhananjaya BL, Nataraju A, Raghavendra Gowda CD, Sharath BK, D'Souza CJ. Vanillic acid as a novel specific inhibitor of snake venom 5 '-nucleotidase: a pharmacological tool in evaluating the role of the enzyme in snake envenomation. Biochemistry (Mosc). 2009;74:13151319.

23. Gitzinger M, Kemmer C, Fluri DA, El-Baba MD, Weber W, Fussenegger $M$. The food additive vanillic acid controls transgene expression in mammalian cells and mice. Nucleic Acids Res. 2012;40:e37.

24. Kim SJ, Kim MC, Um JY, Hong SH. The beneficial effect of vanillic acid on ulcerative colitis. Molecules. 2010;15:7208-7217.

25. Itoh A, Isoda K, Kondoh M, Kawase M, Watari A, Kobayashi M, Tamesada M, Yagi K. Hepatoprotective effect of syringic acid and vanillic acid on CCl4-induced liver injury. Biol Pharm Bull. 2010;33:983-987.

26. Klinger $W$, Kersten $L$. The analeptic effect of vanillic acid diethylamide. Acta Biol Med Ger. 1962;9:67-78.

27. Varma RS, Shukla A, Chatterjee RK. Evaluation of vanillic acid analogues as a new class of antifilarial agents. Indian J Exp Biol. 1993;31:819-821.

28. Fruhmann G, Specht H. Respiratory stimulation with vanillic acid diethylamide in chronic bronchitis and respiratory insufficiency. Med Klin. 1970;65:1570-1576.

29. Mårdh G. Vanillic acid, a metabolite of 4-hydroxy-3-methoxyphenylglycol and 4-hydroxy-3-methoxymandelic acid in man. J Neurochem. 1984:43:522-525.

30. Price J. The dependence of vanillic acid excretion on urinary $\mathrm{pH}$. Clin Chim Acta. 1969;26:413-418.

31. Schmid E, Tautz NA, Bauersachs E, Krautheim J. The excretion of vanilmandelic acid, vanillic acid, homovanillic acid and 5-hydroxyindoleacetic acid by urine in smokers and nonsmokers. Arzneimittelforschung. 1968;18:819-821.

32. Brisse B, Bender F. Excretion of vanillin mandelic acid and vanillic acid in healthy subjects and patients with circulatory and liver diseases. Verh Dtsch Ges Inn Med. 1967;73:1114-1116.

33. Smith P, Bennett AM. Vanillic acid excretion during stress. Nature. 1958;181:709.

34. Guldiken B, Ozkan G, Catalkaya G, Ceylan FD, Ekin Yalcinkaya I, Capanoglu E. Phytochemicals of herbs and spices: Health versus toxicological effects. Food Chem Toxicol. 2018;119:37-49.

35. Brown AC. Liver toxicity related to herbs and dietary supplements: Online table of case reports. Part 2 of 5 series. Food Chem Toxicol. 2017;107:472-501.

36. Tabasum S, Khare S, Jain K. Subchronic Toxicity Assessment of Orally Administered Methanol (70\%) Seed Extract of Abrus precatorius L. in Wistar Albino Rats. Turk J Pharm Sci. 2019;16:88-95.

37. The Organisation of Economic Co-operation and Development (OECD2008), Test No. 407: Repeated Dose 28-day Oral Toxicity Study in Rodents, OECD Guidelines for the Testing of Chemicals, Section 4, OECD Publishing, Paris, 1-13.

38. Hayes AW. Principles and Methods of Toxicology (5th ed). Boca Raton; CRC Press.2007;1223-1245.

39. Greaves P. Histopathology of Preclinical Toxicity Studies: Interpretation and Relevance in Drug Safety Evaluation (4th ed). New York. Academic Press. 2012;1-2.

40. Comptes Rendus Hebdomadaires des Seances, Academie des Sciences. 1956;243:609.
41. Ohta S, Furukawa M, Shinoda M. Studies on chemical protectors against radiation. 1984;104:793-797.

42. ChemIDplus chemical Data Bank. Bethesda (MD): National Library of Medicine (US); 2019 [updated 2019 Apr 4; cited 2019 Apr 13]. Vanillic acid; UNII Number: GM8Q3JM2Y8; [about 3 p.]; Available from: https:// chem.nlm.nih.gov/chemidplus/sid/0000121346

43. Ecobichon, DJ. The Basis of Toxicity Testing. Boca Raton; CRC Press. 1997;94-100

44. Wang J, Sun F, Tang S, Zhang S, Lv P, Li J, Cao X. Safety assessment of vitacoxib: Acute and 90-day sub-chronic oral toxicity studies. Regul Toxicol Pharmacol. 2017;86:49-58.

45. Thanabhorn S, Jaijoy K, Thamaree S, Ingkaninan K, Panthong A. Acute and subacute toxicity study of the ethanol extract from Lonicera japonica Thunb. J Ethnopharmacol. 2006;107:370-373.

46. Hall AP, Elcombe CR, Foster JR, Harada T, Kaufmann W, Knippel A, Küttler K, Malarkey DE, Maronpot RR, Nishikawa A, Nolte T, Schulte A, Strauss $\mathrm{V}$, York MJ. Liver hypertrophy: a review of adaptive (adverse and non-adverse) changes--conclusions from the $3^{\text {rd }}$ International ESTP Expert Workshop. Toxicol Pathol. 2012;40:971-994.

47. Wang J, Sun F, Tang S, Zhang S, Cao X. Acute, mutagenicity, teratogenicity and subchronic oral toxicity studies of diaveridine in rodents. Environ Toxicol Pharmacol. 2015;40:660-670.

48. Nyarko AK, Okine LK, Wedzi RK, Addo PA, Ofosuhene M. Subchronic toxicity studies of the antidiabetic herbal preparation ADD-199 in the rat: absence of organ toxicity and modulation of cytochrome P450. J Ethnopharmacol. 2005;97:319-325.

49. Han CT, Kim MJ, Moon SH, Jeon YR, Hwang JS, Nam C, Park CW, Lee SH, NA JB, Park CS, Park HW, Lee JM, JAng HS, Park SH, Han KG, Choi YW, Lee HY, Kang JK. Acute and 28-Day Subacute Toxicity Studies of Hexane Extracts of the Roots of Lithospermum erythrorhizon in Sprague-Dawley Rats. Toxicol Res. 2015;31:403-414.

50. Kanu KC, Ijioma SN, Atiata O. Haematological, Biochemical and Antioxidant Changes in Wistar Rats Exposed to Dichlorvos Based Insecticide Formulation Used in Southeast Nigeria. Toxics. 2016;4:28.

51. Mathew S, Dushyant S. Interpretation of abnormal liver function tests. Hosp Med Clin. 2014:3:e139-e148.

52. Kluwe WM. Renal function tests as indicators of kidney injury in subacute toxicity studies. Toxicol Appl Pharmacol. 1981;57:414-424.

53. Bhargava AS, Khater AR, Gunzel P. The correlation between lactate dehyrogenase activity in urine and serum and experimental renal damage in the rat. Toxicol Lett. 1978;1:319-332.

54. Unuofin JO, Otunola GA, Afolayan AJ. Evaluation of acute and subacute toxicity of whole-plant aqueous extract of Vernonia mespilifolia Less. in Wistar rats. J Integr Med. 2018;16:335-341.

55. Amresh G, Singh PN, Rao CV. Toxicological screening of traditional medicine Laghupatha (Cissampelos pareira) in experimental animals. J Ethnopharmacol. 2008;116:454-460.

56. Graber M, Corish D. The electrolytes in hyponatremia. Am J Kidney Dis. 1991;18:527-545.

57. Pierro A, De Coppi P. Eaton S. Neonatal physiology and metabolic considerations. In: Coran AG, ed. Pediatric Surgery. Philadelphia; Saunders. 2012;89-107.

58. Satyakam M, Mnas RS. Neelmadhav R. Amitriptyline induced hyponatremia. Delhi Psychiatry Journal. 2014;17:209-210. 